\title{
Aniridia associated with microcornea and subluxated lenses
}

\author{
ROBERT DAVID, ${ }^{1}$ LEONARD MACBEATH, ${ }^{1}$ AND TREFOR JENKINS ${ }^{2}$ \\ From the Department of Ophthalmology, Witwatersrand University School of Medicine and St. John's Eye \\ Hospital, Baragwanath, ${ }^{1}$ and Department of Human Genetics, South African Institute for Medical Research, ${ }^{2}$ \\ Johannesburg, South Africa
}

SUMMARY Four cases of aniridia associated with subluxated lenses and microcornea are presented. The triad occurred in both eyes of the 4 affected members in one Ndebele family (one of the South African Negro tribes). No other ocular or systemic defects were noted, and intelligence was normal. Chromosomal studies on both parents showed no abnormality, and gene marker studies failed to reveal any linkage between the disease locus and a wide range of polymorphic loci.

Aniridia is a congenital anomaly of ectodermal development with an incidence of 1:100 000 (DukeElder, 1964; Warkany, 1971; Podos, 1975) and is transmitted in an autosomal dominant fashion with high penetrance (Sorsby, 1972).

Several other ocular and systemic defects have been associated with aniridia. Among these are foveal aplasia (Warkany, 1971; Sorsby, 1972), subluxated lenses (Duke-Elder, 1964; Podos, 1975) and hypoplastic optic discs (Layman et al., 1974). Associated systemic conditions include mental retardation (Warkany, 1971; Podos, 1975) and Wilms's tumour (Warkany, 1971; Haicken and Miller, 1971).

We report on a family in which four members in 2 generations exhibited the triad of aniridia, microcornea, and upwardly subluxated lenses (Fig. 1).

\section{Case reports}

CASE I/1

A 42-year-old man gave a history of bilateral lens extraction at 15 years of age. On examination the right eye had no light perception, while the left eye, with aphakic correction, had a visio $n$ of $6 / 24$. The intraocular pressure by applanation tonometry was $20 \mathrm{mmHg}$ in both eyes. Both corneae were $8 \mathrm{~mm}$ in the vertical and in the horizontal meridia. A rúdimetary iris was visible as a temporal crescent on both sides (Fig. 2). The angle of the right eye was closed throughout $360^{\circ}$. On gonioscopy some iris

Address for reprints: Dr Robert David, Department of Ophthalmology, Medical School, Hospital Street, Hillbrow 2001, Johannesburg, South Africa rudiment was seen all round and scar tissue in the upper half of the angle. The vitreous in this eye was organised, and no view of the fundus could be obtained. The angle on the left side was open all round

\section{I}

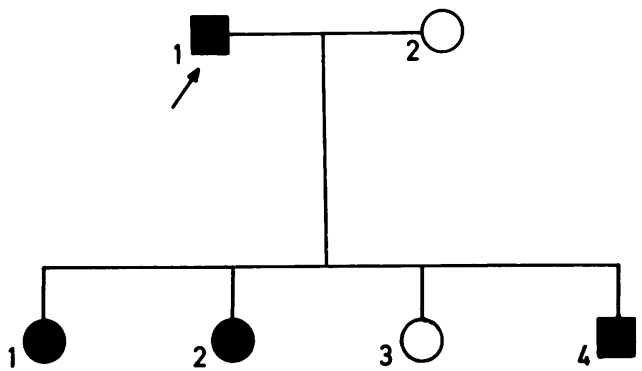

Fig. 1 Pedigree of family with aniridia-microcorneasubluxated lens syndrome

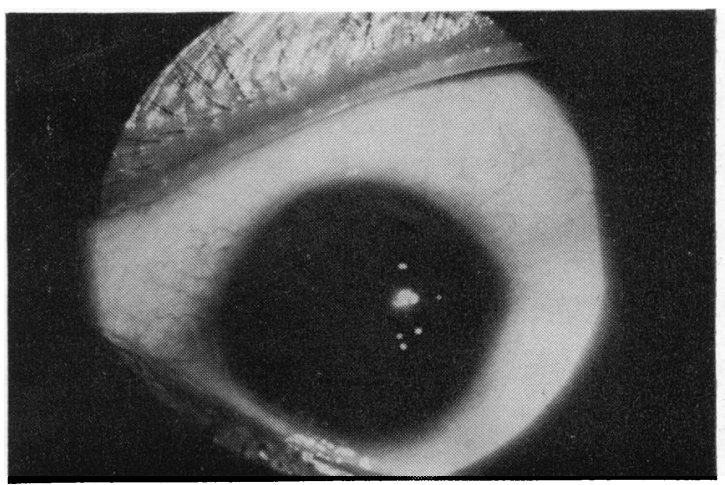

Fig. 2 Left eye of Case I/1 with microcornea and a rudimentary iris crescent 
with iris tissue in the periphery similar to the right eye. Both eyes were apnakic, presumably following the above-mentioned surgery, and the fundus showed no significant abnormalities. A mild horizontal nystagmus could be detected.

\section{CASE I/2}

This patient, a 38-year-old woman, was the wife of Case 1/1. She became blind in early childhood after an unknown bilateral eye disease of which she could give us no details. She attended a blind school and it was there she met her husband. Examination revealed absence of light perception in both eyes. The right eye was phthisical with a pressure of $0 \mathrm{mmHg}$. The left eye had a pressure of $10 \mathrm{mmHg}$, a shallow anterior chamber, and a totally occluded pupil with a complicated cataract. Both corneae were normal in size.

\section{CASE II $/ 1$}

A 15-year-old girl, daughter of the previous two cases, had a visual acuity with aphakic correction of $6 / 24$ in both eyes. She had a horizontal nystagmus, and the intraocular pressure was $20 \mathrm{mmHg}$ in each eye. The corneal diameter measured $7.0 \mathrm{~mm}$ horizontally in both eyes, while the vertical measurements were $8.5 \mathrm{~mm}$ on the right and $7.5 \mathrm{~mm}$ on the left. Both lenses were subluxated upwards, with the lower margin of the lens just above the visual axis. The lens on the right was opaque (Fig. 3), while that on the left showed early cortical opacities. Gonioscopy revealed rudimentary iris tissue all round and an open angle with normal structures (Fig. 4). Both fundi were normal.

\section{CASE II $/ 2$}

A 13-year-old girl, sister of the previous case, had a visual acuity limited to light perception in the right eye and 6/18 in the left, with aphakic correction. The

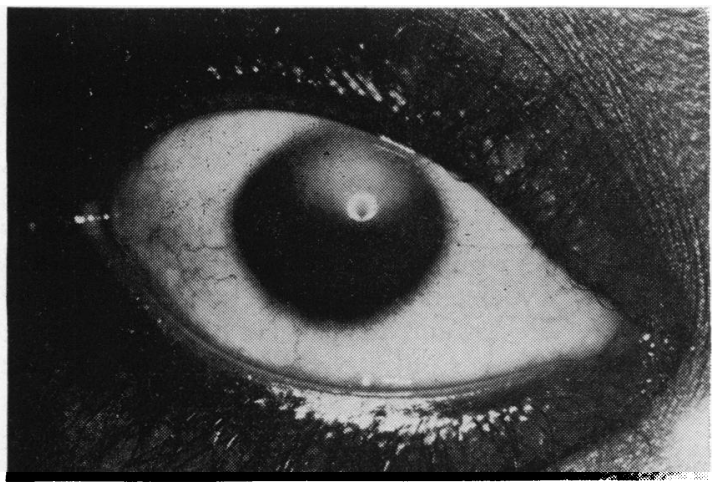

Fig. 3. Right eye of patient II/1. Microcornea aniridia and subluxated cataractous lens

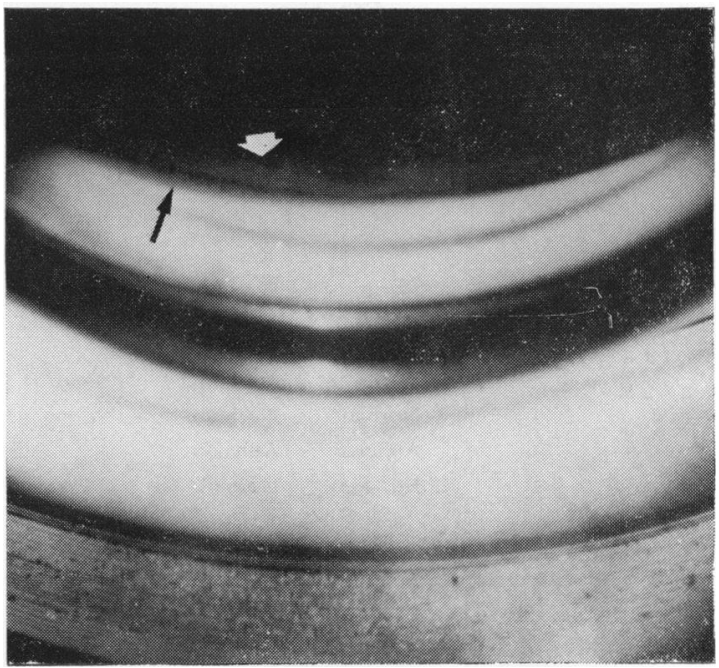

Fig. 4 Gonioscopic view of angle (black arrow) and iris rudiment (white arrow)

corneal diameters were $7.00 \mathrm{~mm}$ in the horizontal meridian of both eyes, while the vertical measurement was $8.0 \mathrm{~mm}$ on the right and $8.5 \mathrm{~mm}$ on the left side. Again, there was a horizontal nystagmus, and the intraocular pressure was $6 \mathrm{mmHg}$ on the right and $18 \mathrm{mmHg}$ on the left. The right eye had undergone lens surgery, and when seen had a longstanding detached retina with pronounced flare and cells in the anterior chamber. The left eye showed upward subluxation of the lens, identical to Case II/1. On gonioscopy, on the right side iris tissue was present only on the temporal periphery; on the left side iris tissue was present in a rudimentary form all round. The angles were open with similar normal structures as in the previous case. The fundus of the left eye was normal.

CASE II $/ 3$

A 9-year-old girl (Fig. 4), sister of the other 2, had a visual acuity of $6 / 9$ on the right and $6 / 7.5$ on the left, both with small myopic-astigmatic corrections. Intraocular pressures were $16 \mathrm{mmHg}$ on the right and $14 \mathrm{mmHg}$ on the left. The corneae were normal in size, the iris and pupil normal in appearance. Neither lens was subluxated, but early peripheral cortical opacities were present in both temporal aspects. The angles were open all round and normal. Both fundi were also normal.

CASE II $/ 4$

An 8-year-old boy, was the youngest child of Cases $I / 1$ and $I / 2$. The visual acuity with or without aphakic correction was $6 / 60$ in both eyes, with the lower margin of the lens bisecting the visual axis, 
Table 1 Summary of ocular findings in the 4 affected patients

\begin{tabular}{|c|c|c|c|c|c|c|c|c|}
\hline \multirow[b]{2}{*}{ Findings } & \multicolumn{2}{|l|}{$I / 1$} & \multicolumn{2}{|c|}{$I I / I$} & \multicolumn{2}{|l|}{$I I / 2$} & \multicolumn{2}{|c|}{$I I / .1$} \\
\hline & $R E$ & $L E$ & $R E$ & $L E$ & $R E$ & $L E$ & $R E$ & $L E$ \\
\hline Visual acuity & No PL & $6 / 24$ & $6 / 24$ & $6 / 24$ & LP & $6 / 18$ & $6 / 60$ & $6 / 60$ \\
\hline $\begin{array}{l}\text { Corneal diameter: } \\
\text { Horizontal } \\
\text { Vertical }\end{array}$ & $\begin{array}{l}8 \\
8\end{array}$ & $\begin{array}{l}8 \\
8\end{array}$ & $\begin{array}{l}7 \\
8 \cdot 5\end{array}$ & $\begin{array}{l}7 \\
7 \cdot 5\end{array}$ & $\begin{array}{l}7 \\
8\end{array}$ & $\begin{array}{l}7 \\
8 \cdot 5\end{array}$ & $\begin{array}{l}8 \\
8\end{array}$ & $\begin{array}{l}7 \\
8\end{array}$ \\
\hline Intraocular pressure & 20 & 20 & 22 & 20 & 6 & 18 & 14 & 14 \\
\hline Sublux. lens & Aphakic & Aphakic & Upwards & Upwards & Aphakic & Upwards & Upwards & Upwards \\
\hline I ris on direct view & $\begin{array}{r}\text { Temporal } \\
\text { crescent }\end{array}$ & $\begin{array}{l}\text { Temporal } \\
\text { crescent }\end{array}$ & None & None & None & $\begin{array}{l}\text { Temporal } \\
\text { crescent }\end{array}$ & $\begin{array}{l}\text { Temporal } \\
\text { crescent }\end{array}$ & None \\
\hline Angle & Normal & Normal & Normal & Normal & Normal & Normal & Normal & Normal \\
\hline Cataract & Aphakic & Aphakic & + & Early & Aphakic & - & - & - \\
\hline Fundus & Not seen & Normal & Normal & Normal & $\begin{array}{l}\text { Total retinal } \\
\text { detachment }\end{array}$ & Normal & Normal & Normal \\
\hline Nystagmus & & \pm & & + & & + & & \\
\hline
\end{tabular}

The intraocular pressure was $14 \mathrm{mmHg}$ in both eyes. The right cornea measured $8.0 \mathrm{~mm}$ in both meridia, while the left measured $7.0 \mathrm{~mm}$ horizontally and $8 \mathrm{~mm}$ vertically. Both lenses were clear and subluxated upwards in a similar manner to the previous cases. Examination of the angles revealed very rudimentary iris present throughout the angles with the rest of the angle appearing normal. Both discs and maculae looked normal. The child had a marked nystagmus. The ocular findings of the affected cases are summarised in Table 1.

\section{Discussion}

Aniridia is a well documented congenital anomaly, transmitted as an autosomal dominant trait with 85-90\% penetrance (Sorsby, 1972). When aniridia is transmitted as a dominant trait, the associated ocular manifestations usually show great variability (Drenckhahn and Behnke, 1961). Among these either microcornea (Duke-Elder, 1964) or subluxated lenses (Duke-Elder, 1964; Drenckhahn and Behnke, 1961; Warkany, 1971) have been described. To the best of our knowledge, however, there has been no report in which both have coexisted in the same patient. Likewise no defect in the angle of the anterior chamber was apparent, and for this reason none of our patients showed features of glaucoma.

As microphthalmos has been frequently associated with aniridia or with subluxated lenses (DukeElder, 1964; Sorsby, 1972), we undertook ultrasound investigations, which demonstrated normal axial lengths on the A-mode (Fig. 5) and showed normal structures, with the subluxated lens detectable on the B-mode (Fig. 6). It is of interest to note that the posterior segment of the eye in all patients revealed neither a hypoplastic disc (Layman et al.,

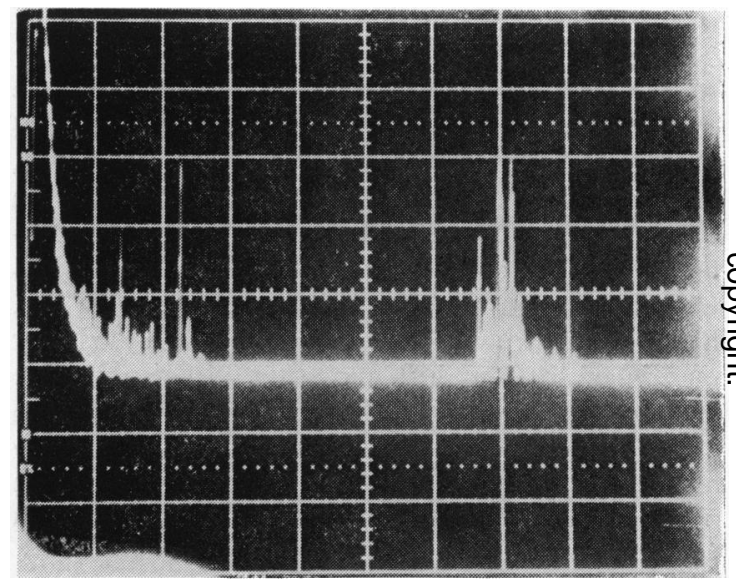

Fig. 5 A-mode ultrasound of left eye of patient II/2; normal axial length

1974), nor macular or foveal aplasia (Warkany, 1971; Podos, 1975; Sorsby, 1972).

None of the patients was mentally retarded. The father is the breadwinner and supports his family, while the children, in spite of their visual handicap, contrive to attend regular school.

No specific search was made for Wilms's tumour, but the patients' apparent good health at ages ranging from 9 to 42 renders this association highly unlikely. This would support the view that Wilms's tumour is associated mainly with sporadic cases of aniridia (Haicken and Miller, 1971).

Chromosomal studies were performed on the 2 parents, and the results were normal.

Dominantly inherited conditions afford an opportunity for establishing the relationship of the disease locus to loci determining the inheritance of normal genetic traits like the blood groups. In this 
Table 2 Serogenetic data on all family members*

\begin{tabular}{|c|c|c|c|c|c|c|}
\hline & $\begin{array}{l}I / I \\
(A) \uparrow\end{array}$ & $\begin{array}{l}1 / 2 \\
(U)\end{array}$ & $\begin{array}{l}I I / I \\
(A)\end{array}$ & $\begin{array}{l}I I / 2 \\
(A)\end{array}$ & $\begin{array}{l}I I / .3 \\
(U)\end{array}$ & $\begin{array}{l}I I / \cdot 1 \\
(A)\end{array}$ \\
\hline \multicolumn{7}{|l|}{ Red cell antigens } \\
\hline ABO & $\mathrm{O}$ & $\mathbf{A}_{1}$ & $\mathrm{O}$ & $A_{1}$ & $\mathrm{O}$ & $\mathbf{O}$ \\
\hline MNSs & $\mathrm{Ms} / \mathrm{Ns}$ & $\mathrm{Ms} / \mathrm{Ms}$ & $\mathrm{Ms} / \mathrm{Ns}$ & $\mathrm{Ms} / \mathrm{Ms}$ & $\mathrm{Ms} / \mathrm{Ns}$ & $\mathrm{Ms} / \mathrm{Ns}$ \\
\hline Rhesus (probable) & $\mathbf{R}_{\mathbf{1}} / \mathbf{R}_{\mathbf{2}}$ & Ro/Ro & $R_{1} /$ Ro & $R_{1} / R_{o}$ & $R_{1} /$ Ro & $R_{1} /$ Ro \\
\hline Duffy & $\mathrm{Fy} \mathrm{y}^{\mathrm{a}} / \mathrm{Fy}$ & $F y^{: / / F y}$ & $F y^{a} / F y$ & $F y^{a} / F y$ & $\mathrm{Fy} / \mathrm{Fy}$ & $\mathrm{Fy} / \mathrm{Fy}$ \\
\hline ABH Secretor & $\mathrm{Se} / \mathrm{se}$ & $\mathrm{Se} /$ & $\mathrm{Se} / \mathrm{se}$ & $\mathrm{Se} / \mathrm{se}$ & $\mathrm{Se} / \mathrm{se}$ & $\mathrm{Se} / \mathrm{se}$ \\
\hline \multicolumn{7}{|l|}{ Redl cell enzymes } \\
\hline 6GPD & $\mathrm{AC}$ & $\mathbf{A}$ & A & $\mathbf{A}$ & $\mathbf{A}$ & $\mathbf{A}$ \\
\hline PepA & $1-1$ & $2-1$ & $2-1$ & $1-1$ & $2-1$ & $1-1$ \\
\hline CAII & $2-1$ & $1-1$ & $2-1$ & $2-1$ & $2-1$ & $2-1$ \\
\hline GPT & $2-1$ & $2-1$ & $2-2$ & $2-1$ & $2-1$ & $1-1$ \\
\hline GSH & $1-1$ & $1-\mathrm{F}$ & $1-1$ & $1-1$ & $1-1$ & $1-1$ \\
\hline $\begin{array}{l}\text { Serum proteins } \\
\mathrm{Hp}\end{array}$ & $2-1$ & $2-1$ & $0-0$ & $2-1$ & $0-0$ & $2-1$ \\
\hline
\end{tabular}

* Red cell antigen typing carried out according to standard methods (Race and Sanger, 1975), and enzyme and protein typing according to methods outlined by Giblett (1969)

tThe letter $\mathbf{A}$ indicates individuals affected with the syndrome; $U$ indicates an unaffected individual

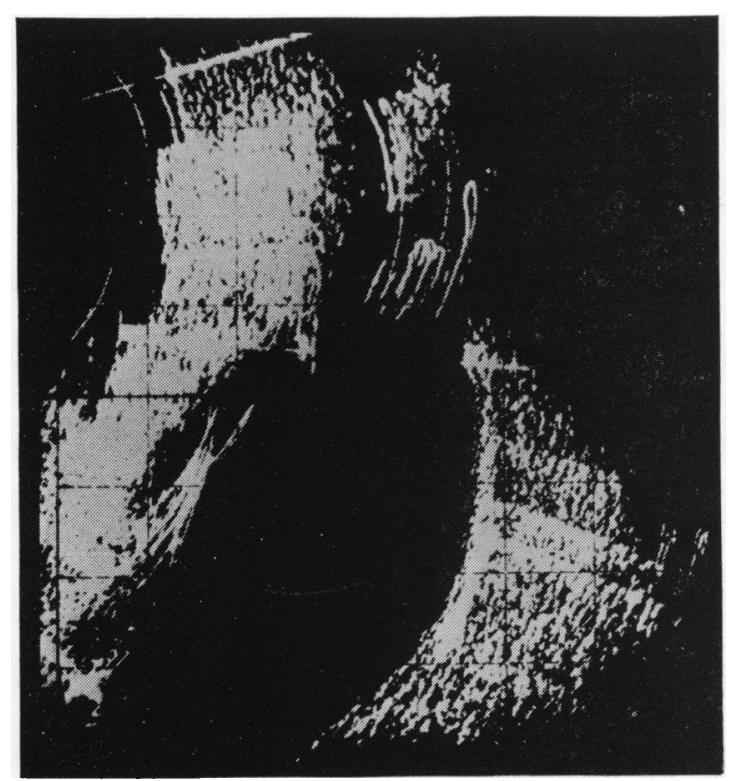

Fig. 6 B-mode ultrasound of left eye of patient II/2 with subluxated lens seen below

family such a study has been attempted. All family members were tested for a wide range of genetic polymorphisms. No variation was found in the $\mathbf{P}$ and Kell blood group systems or in the following red cell enzyme systems: glucose 6-phosphate dehydrogenase (G6PD), adenosine deaminase (ADA), acid phosphatase (AP), phosphoglucomutases $\left(\mathrm{PGM}_{1}\right.$ and $\mathrm{PGM}_{2}$ ), peptidase $\mathrm{D}$ (pep D) esterase (est D), adenylatekinase $(\mathrm{AK})$, carbonic anhydrase $\left(\mathrm{CA}_{1}\right)$, and isocitrate dehydrogenase (ICD). The serum transference pattern was $\mathrm{C}$ in all family.

The findings in the other systems are presented in Table 2, from which it will be seen that very close linkage is excluded between the locus for the aniridia-microcornea-subluxated lens syndrome and the MNS, rhesus, Duffy, 6-phosphogluconate dehydrogenase, and carbonic anhydrase II loci. The data are presented in full to enable those workers with access to families suffering from the same condition to combine their findings with these in an attempt to establish genetic linkage.

References

Drenckhahn, F. O., and Behnke, H. (1961). Variability in clinical manifestations of IMS defects in 2 families with aniridia. Klinische Monatsblätter für Augenheilkunde, 138, 545-557.

Duke-Elder, S. (1964). System of Ophthalmology, Vol. 3, part 2, p. 567. Kimpton: London.

Giblett, E. R. (1969). Genetic Markers in Human Blood. Blackwell Scientific Publications: Oxford.

Haicken, B. N., and Miller, D. R. (1971). Simultaneous occurrence of congenital aniridia, hamartoma and Wilms's tumor. Journal of Pediatrics, 78, 497-502.

Layman, P. R., Anderson, D. R., and Flynn, J. T. (1974). Frequent occurrence of hypoplastic optic disc in patients with aniridia. American Journal of Ophthalmology, 77, 513-516.

Podos, S. M. (1975). Aniridia in Birth Defects, p. 165. Edited by D. Bregsma. Williams \& Wilkins: Baltimore.

Race, R. R., and Sanger, R. (1975). Blood Groups in Man, 6th edn. Blackwell Scientific Publications: Oxford.

Sorsby, A. (1972). Maldevelopmental Defects in Modern Ophthalmology, 2nd edn., vol. 3, p. 234. Butterworth: London.

Warkany, J. (1971). Congenital Malformations. Year Book Medical Publishers: Chicago. 